\title{
KEBERLAKUAN YURIDIS PERATURAN DESA \\ DALAM PERSPEKTIF ASAS FORMAL KELEMBAGAAN PEMBENTUKAN PERATURAN PERUNDANG-UNDANGAN
}

Oleh:

Muhammad Syirazi Neyasyah

Fakultas Hukum Universitas Indonesia

Email : syirazineyasyah@gmail.com

\begin{abstract}
This paper raises the legal issue regarding the juridical enactment of Village Regulations seen from the perspective of the formal principle of the institution of the formation of legislation in accordance with the principles of the formation of legislation stipulated in Law Number 12 of 2011 concerning the Establishment of Legislation. Identification of the problem under study is how does the juridical enactment of Village Regulations be seen from the perspective of the formal principle of the formation of legislation? Can the Village Consultative Body as a village head partner in forming Village Regulations be qualified as an institution for establishing village legislation? This research is normative legal research, using a statute approach, utilizing primary, secondary and tertiary legal materials. Analysis of legal material is carried out using qualitative analysis, with deductive reasoning. The results showed that the juridical enactment of Village Regulations was viewed from the perspective of the formal institutional principle of formation, because the Village Consultative Body could not qualify as a Village Representative Body, whereas according to the formal principle of establishing good village regulations, Village Regulations were made by the Village Representative Body together with the head village. The village does not have a Village Representative Body, but a Village Consultative Body. Therefore the Village Regulations established by the Village Consultative Body together with the village head did not fulfill the principle of juridical enforceability, which emphasized that the legislation must be formed by the appropriate forming institution, in this case, the Village Representative Body together with the village head.
\end{abstract}

Keywords: enforceability, juridical, formal principles, institutions, village regulations.

\begin{abstract}
ABSTRAK
Tulisan ini mengangkat isu hukum mengenai keberlakuan yuridis Peraturan Desa dilihat dari perspektif asas formal kelembagaan pembentukan peraturan perundang-undangan sesuai dengan asas pembentukan peraturan perundang-undangan yang diatur dalam Undang-Undang Nomor 12 Tahun 2011 tentang Pembentukan Peraturan Perundang-undangan. Identifikasi masalah yang diteliti yaitu bagaimanakah keberlakuan yuridis Peraturan Desa dilihat dari perspektif asas formal kelembagaan pembentukan peraturan perundang-undangan? Apakah Badan Permusyawaratan Desa sebagai mitra kepala desa dalam membentuk Peraturan Desa dapat dikualifikasikan sebagai kelembagaan pembentukan peraturan perundang-undangan di desa? Penelitian ini merupakan penelitian hukum normatif, dengan menggunakan pendekatan peraturan perundang-undangan (statute approach), memanfaatkan bahan hukum primer, sekunder dan bahan hukum tersier. Analisis bahan hukum dilakukan dengan menggunakan analisis kualitatif, dengan penalaran deduktif. Hasil penelitian menunjukkan bahwa keberlakuan yuridis Peraturan Desa Peraturan Desa dilihat dari perspektif asas formal kelembagaan pembentukannya, karena Badan Permusyawaratan Desa tidak dapat
\end{abstract}


dikualifikasikan sebagai Badan Perwakilan Desa, padahal menurut asas formal pembentukan peraturan desa yang baik, Peraturan Desa dibuat oleh Badan Perwakilan Desa bersama dengan kepala desa. Desa tidak memiliki Badan Perwakilan Desa, melainkan Badan Permusyawaratan Desa. Oleh karena itu Peraturan Desa yang dibentuk Badan Permusyawaratan Desa bersama kepala desa tidak memenuhi asas keberlakuan yuridis, yang menekankan bahwa Peraturan perundang-undangan harus dibentuk oleh kelembagaan pembentuk yang tepat, dalam hal ini Badan Perwakilan Desa bersama dengan kepala desa.

Kata Kunci: keberlakuan, yuridis, asas formal, kelembagaan, peraturan desa.

\section{Pendahuluan}

Asas formal atau asas pembentukan peraturan perundang-undangan mengatur salah satu syarat yang harus dipenuhi dalam pembentukan peraturan perudnang-undangan yaitu asas kelembagaan atau pejabat pembentuk yang tepat. Makna "asas kelembagaan atau pejabat pembentuk yang tepat" adalah bahwa setiap jenis Peraturan Perundang-undangan harus dibuat oleh lembaga negara atau pejabat Pembentuk Peraturan Perundang-undangan yang berwenang. Peraturan Perundang-undangan tersebut dapat dibatalkan atau batal demi hukum apabila dibuat oleh lembaga negara atau pejabat yang tidak berwenang. ${ }^{1}$ Peraturan Desa meskipun sekarang ini tidak lagi dimasukkan ke dalam susunan hierarkhi peraturan perudnang-undangan Indonesia, naun dalam proses pembentukannya wajib taat asas terhadap asas formal yang diatur dalam Undang-Undang Nomor 12 Tahun 2011 tentang Peraturan Perundang-undangan.

\footnotetext{
${ }^{1}$ Penjelasan Pasal 5 huruf $\mathrm{b}$ Undang-Undang Nomor 12 Tahun 2011 tentang Pembentukan Peraturan Perundang-undangan.
}

Keharusan tersebut diatur tegas dalam Pasal 32 Ayat (1) Peraturan Menteri Dalam Negeri Republik Indonesia Nomor 111 Tahun 2014 tentang Pedoman Teknis Peraturan Di Desa yang berbunyi "Ketentuan mengenai teknik penyusunan Peraturan di Desa dan Keputusan Kepala Desa sesuai dengan ketentuan Undang-Undang tentang Pembentukan Peraturan Perundangundangan". Dalam Pasal 69 ayat (1) UndangUndang Nomor 6 Tahun 2014 tentang Desa, "Jenis peraturan di Desa terdiri atas Peraturan Desa, peraturan bersama Kepala Desa, dan peraturan Kepala Desa”. Dengan demikian setiap pembentukan peraturan di desa, dalam kajian ini Peraturan Desa harus taat asas terhadap asas formal dan asas material pembentukan peraturan perundangundangan.

Asas formal atau asas pembentukan Peraturan Perundang-undangan yang baik, sebagaimana disinggung terdahulu, diantaranya asas kelembagaan atau pejabat pembentuk yang tepat. Dalam konteks pembentukan Peraturan Desa, maka 
kelembagaan yang berwenang membentuk Peraturan Desa tentunya dua lembaga demokrasi yang terdapat dalam organisasi pemerintahan desa, yaitu Badan Perwakilan Desa dan kepala desa. Pertama kalinya keberadaan Badan Perwakilan Desa diatur dalam Pasal 104 Undang-Undang Nomor 22 Tahun 1999 yang berbunyi "Badan Perwakilan Desa atau yang disebut dengan nama lain berfungsi mengayomi adat istiadat, membuat Peraturan Desa, menampung dan menyalurkan aspirasi masyarakat, serta melakukan pengawasan terhadap penyelenggaraan Pemerintahan Desa". Anggota Badan Perwakilan Desa dipilih dari dan oleh penduduk Desa yang memenuhi persyaratan. Badan Perwakilan Desa bersama dengan Kepala Desa menetapkan Peraturan Desa. $^{2}$ Badan Perwakilan Desa jelas merupakan institusi politik demokrasi desa, sama halnya dengan kepala desa, yang dipilih langsung oleh penduduk desa, dan diberi wewenang antara lain membentuk Peraturan Desa.

Pertanyaan yang mengemuka, keberadaan Badan Perwakilan Desa sebagai institusi demokrasi di desa yang semula diatur dalam Undang-Undang Nomor 22 Tahun 1999 tentang Pemerintahan Daerah, sudah dihapus bersamaan dengan dicabut dan digantinya Undang-Undang Nomor 22 Tahun

\footnotetext{
${ }^{2}$ Pasal 105 ayat (1) dan ayat (3) Undang-Undang Nomor 12 Tahun 2011 tentang Pembentukan Peraturan Perundang-undangan.
}

1999 tentang Pemerintahan Daerah dengan Undang-Undang Nomor 32 Tahun 2004 tentang Pemerintahan Daerah. Badan Perwakilan Desa pun dihapus dan diubah menjadi Badan Permusyawaratan Desa, dengan Badan Permusyawaratan Desa berfungsi menetapkan peraturan desa bersama kepala desa, ${ }^{3}$ Anggota badan permusyawaratan desa adalah wakil dari penduduk desa bersangkutan yang ditetapkan dengan cara musyawarah dan mufakat. ${ }^{4}$

Pemerintahan Negara Republik Indonesia membagi daerah dalam Negara Kesatuan Republik Indonesia atas daerahdaerah provinsi dan daerah provinsi itu dibagi atas kabupaten dan kota, yang tiaptiap provinsi, kabupaten, dan kota itu mempunyai pemerintahan daerah, yang diatur dengan undang-undang. ${ }^{5}$ Daerah kabupaten/kota dibagi atas Kecamatan dan Kecamatan dibagi atas kelurahan dan/atau Desa. $^{6}$ Desa dalam struktur pemerintahan Negara Kesatuan Republik Indonesia yang dikukuhkan dengan Undang-Undang Nomor 6 Tahun 2014 tentang Desa memiliki bentuk dan susunan tingkatan pemerintahan sendiri sebagai satuan pemerintahan terendah. Pemerintahan desa merupakan sub sistem dari sistem penyelenggaraan pemerintahan

\footnotetext{
${ }^{3}$ Pasal 209 Undang-Undang Nomor 32 Tahun 2004 tentang Pemerintahan Daerah

${ }^{4}$ Pasal 210 ayat (1)

${ }^{5}$ Pasal 18 ayat (1) Undang-Undang Dasar Negara Republik Indonesia Tahun 1945

${ }^{6}$ Pasal 2 ayat (3) Undang-Undang Nomor 23 Tahun 2014 tentang Pemerintahan Daerah.
} 
nasional yang langsung berada di daerah, bersama-sama dengan pemerintah daerah provinsi dan kabupaten/kota, kedudukannya bukan lagi sebagai perangkat daerah kabupaten/kota. Era reformasi melahirkan gagasan pemberian otonomi pada Desa sebagai bagian pemerintahan terkecil dari Negara Kesatuan Republik Indonesia yang diharapkan mampu secara mandiri mencapai tujuan pembangunan sehingga memberikan dampak besar bagi perekonomian negara secara keseluruhan. Desa dan adat istiadatnya telah menjadi ciri khusus dari Indonesia sejak jaman pra-kemerdekaan sehingga memberikan otonomi yang utuh pada Desa merupakan upaya yang tepat untuk mencapai kesejahteraan rakyat. Gagasan ini bermula dari pendapat Muhammad Yamin yang menyatakan bahwa Desa merupakan" kaki” dari Pemerintah Indonesia untuk menjalankan fungsi pemerintahan secara optimal, dengan pemerintah desa menjadi representasi Negara (hadir) di tengah-tengah rakyat, mengingat Pemerintahan Desa langsung bersentuhan dengan masyarakat. ${ }^{7}$

Hanif Nurcholis menegasi pandangan pendiri negara (the founding father), dan menyatakan bahwa "Desa, kuria, marga, gampong dan lain-lain ditarik ke dalam sistem pemerintahan atau tidak dibiarkan berada di luar sebagaimana kebijakan

7 Moh. Yamin dalam Ni'matul Huda, 2014, Perkembangan Hukum Tata Negara (Perdebatan dan Gagasan Penyempurnaan), Yogyakarta: FH-UII Press, hlm. 2. pemerintah kolonial." ${ }^{\text {8 }}$ Oleh karena itu urgensi dari upaya-upaya pembangunan desa merupakan sebuah keharusan dan desa merupakan pintu awal terciptanya kesejahteraan, maka dari itu harusnya kewenangan desa mengatur diri sendiri bagi pemerintahan desa juga diiringi oleh wewenang membentuk Peraturan Desa yang menjadi instrumen bagi pemerintah desa dalam menjalankan urusan rumah tangga desa.

Konsep otonomi desa memberikan keleluasan pada desa untuk mengatur desanya sendiri termasuk dalam hal membuat kebijakan. Atas dasar itulah Undang-Undang tentang Desa dan peraturan pelaksanaannya mengatur wewenang desa dalam pembuatan Peraturan Desa. Secara historis, konstruksi hukum Peraturan Desa menjadi penting pasca era reformasi dengan diaturnya permasalahan ini dalam tiga Undang-Undang, yaitu Undang-Undang Nomor 22 Tahun 1999 tentang Pemerintahan Daerah, yang kemudian dicabut dan diganti dengan Undang-Undang Nomor 32 Tahun 20014 tentang Pemerintahan Daerah, kemudian Undang-Undang Nomor 6 Tahun 2014 tentan Desa.

Kedudukan Peraturan Desa pada masa berlakunya Undang-Undang Nomor 22 Tahun 1999 tentang Pemerintahan Daerah,

8 Hanif Nurcholis, 2012, Pertumbuhan dan Penyelenggaraan Pemerintahan Desa, Surabaya: Erlangga, hlm. 212. 
sangat kuat, di mana desa memiliki institusi politik demokrasi yakni Badan Perwakilan Desa, ${ }^{9}$ yang bersama-sama dengan pemerintah desa merupakan penyelenggara Pemerintahan Desa, di mana Badan Perwakilan Desa berfungsi mengayomi adat istiadat, membuat Peraturan Desa, menampung dan menyalurkan aspirasi masyarakat, serta melakukan pengawasan terhadap penyelenggaraan Pemerintahan Desa. $^{10}$ Peraturan Desa yang secara kelembagaan dibentuk oleh Badan Perwakilan Desa dengan persetujuan Kepala Desa, dikukuhkan pula ke dalam hierarkhi peratuan perundang-undangan Indonesia sebagaimana diatur dalam Pasal 7 ayat (2) Undang-Undang Nomor 10 Tahun 2004 tentang Pembentukan Peraturan Perundangundangan, yang memposisikan Peraturan Desa sebagai kualifikasi produk hukum daerah bersama-sama dengan Peraturan Daerah provinsi dibuat oleh dewan perwakilan rakyat daerah provinsi bersama dengan gubernur; Peraturan Daerah kabupaten/kota dibuat oleh dewan perwakilan rakyat daerah kabupaten/kota bersama bupati/walikota; dan Peraturan Desa/peraturan yang setingkat, dibuat oleh badan perwakilan desa atau nama lainnya bersama dengan kepala desa atau nama lainnya.

\footnotetext{
${ }^{9}$ Undang-Undang Nomor 22 Tahun 1999 tentang Pemerintahan Daerah, Pasal 94.

${ }^{10}$ Undang-Undang Nomor 22 Tahun 1999 tentang Pemerintahan Daerah, Pasal 104.
}

Keberadaan Peraturan Desa sebagai bagian dari hierarkhi hokum positif nasional tidak bertahan lama, karena terjadinya perubahan regulasi pemerintahan daerah, yakni dicabut dan digantinya Undang Nomor 22 Tahun 1999 tentang Pemerintahan Daerah, dengan Undang-Undang Nomor 32 Tahun 2004 tentang Pemerintahan Daerah. Undang-Undang ini menghapus institusi demokrasi desa "Badan Perwakilan Desa" diganti dengan "Badan Permusyawaratan Desa”. Menindaklanjuti hadirnya UndangUndang Nomor 32 Tahun 2004 tentang Pemerintahan Daerah, terjadi pula perubahan atas Undang-Undang Nomor 10 Tahun 2004 tentang Pembentukan Peraturan Perundangundangan, yang dicabut dan diganti dengan Undang-Undang Nomor 12 Tahun 2011 tentang Pembentukan Peraturan PerundangUndangan, yang bersamaan dengan itu, menghapus keberadaan Peraturan Desa dari hierarkhi Peraturan Perundang-undangan Indonesia.

Kemudian dengan lahirnya UndangUndang Desa, memberikan dimensi-dimensi baru bagi desa dalam mengurus kemandiriannya juga diikuti perubahan norma terkait Peraturan Desa dalam sistem peraturan perundang-undangan di Indonesia. Hal tersebut menimbulkan permasalahan hukum, terutama menyangkut posisi Peraturan Desa, yang sudah dikeluarkan dari hierarkhi sebagaimana diatur dalam Pasal 7 Undang-Undang Nomor 12 Tahun 2011 
tentang Peraturan Perundang-Undangan, kemudian Undang-Undang Desa mengatur tersendiri adanya wewenang desa membentuk Peraturan Desa, akan tetapi sangat disayangkan Undang-Undang Desa hanya menguatkan wewenang desa membentuk Peraturan Desa wewenang tanpa diikuti dengan mereposisikan institusi demokrasi desa menjadi Badan Perwakilan Desa, yang mempunyai fungsi layaknya lembaga perwakilan, untuk dan atas nama penduduk desa bersama-sama dengan Kepala Desa membentuk Peraturan Desa.

$$
\text { Undang-Undang Nomor } 12 \text { Tahun }
$$
2011 tentang Peraturan PerundangUndangan, dalam Pasal 8 aat (1) hanya menyebut produk hukum desa berupa Peraturan Kepala Desa, yang dibuat oleh Kepala Desa, yang seharusnya berfungsi sebagai peraturan pelaksana atas Peraturan Desa.

Konstruksi hukum dari kedua norma dalam Undang-Undang Pembentukan Peraturan Perundang-Undangan telah menimbulkan tanda tanya terhadap keberadaan Peraturan Desa sebagai akibat dari reposisi tersebut. Apa lagi peraturan desa apabila diidentifikasi secara khusus memiliki kemiripan dengan peraturan daerah seperti yang diatur dalam Pasal 69 Undang-Undang Desa yang berbunyi:

(1) Jenis peraturan di Desa terdiri atas Peraturan Desa, peraturan bersama
Kepala Desa, dan peraturan Kepala Desa.

(2) Peraturan sebagaimana dimaksud pada ayat (1) dilarang bertentangan dengan kepentingan umum dan/atau ketentuan peraturan perundang-undangan yang lebih tinggi.

(3) Peraturan Desa ditetapkan oleh Kepala Desa setelah dibahas dan disepakati bersama Badan Permusyawaratan Desa.

(4) Rancangan Peraturan Desa tentang Anggaran Pendapatan dan Belanja Desa, pungutan, tata ruang, dan organisasi Pemerintah Desa harus mendapatkan evaluasi dari Bupati/Walikota sebelum ditetapkan menjadi Peraturan Desa.

(5) Hasil evaluasi sebagaimana dimaksud pada ayat (4) diserahkan oleh Bupati/Walikota paling lama 20 (dua puluh) hari terhitung sejak diterimanya rancangan peraturan tersebut oleh Bupati/Walikota.

Di satu sisi Undang-Undang Desa telah menempatkan Peraturan Desa sebagai aspek penting dalam menopang pelaksanaan pemerintahan desa. Berdasarkan uraian di atas, diidentifikasi permasalahan yaitu apakah yang menjadi pertimbangan pembentuk Undang-Undang dalam menghapus Peraturan Desa dari tata urutan Peraturan Perundang-undangan di Indonesia? Bagaimanakah kedudukan Peraturan Desa 
yang pembentukannya diamanatkan oleh Undang-Undang Desa dilihat dari asas formal pembentukan peraturan perundangundangan Indonesia?

\section{Metode Penelitian}

Penelitian ini merupakan penelitian hukum normatif, dengan menggunakan pendekatan peraturan perundang-undangan (statute aproach), yakni dilakukan dengan menelaah peraturan perundang-undangan yang bersangkut paut dengan isu hukum yang sedang ditangani, dalam hal ini kedudukan Peraturan Desa. ${ }^{11}$ Penyajian bahan hukum dalam penelitian ini bersifat deskriptif analitis yang mengungkapkan peraturan perundang-undangan yang berkaitan dengan teori-teori hukum dan bahan-bahan non hukum yang ada relevansinya dengan objek permasalahan yang diteliti melalui penelusuran kepustakaan hukum (library law research). ${ }^{12}$ Kajian ini bertujuan memberikan gambaran secara rinci, sistematis, dan menyeluruh mengenai segala sesuatu yang berkaitan dengan kedudukan dan keberlakuan yuridis Peraturan Desa setelah dihilangkannya Peraturan Desa dari Undang-Undang Pembentukan Peraturan PerundangUndangan dan dimunculkan pada Undang-

11 Peter Mahmud Marzuki, 2010, Penelitian Hukum, Cetakan ke-6, Jakarta: Kencana Prenada Media Group, hlm. 93.

${ }^{12}$ Zainuddin Ali, 2009, Metode Penelitian Hukum, Jakarta: Sinar Grafika, hlm. 57 dan 105.
Undang Desa. Analisis bahan hukum dilakukan dengan menggunakan analisis yuridis kualitatif, artinya dengan bertitik tolak pada ketentuan peraturan perundangundangan yang berlaku yang berkembang melalui pembahasan dalam bahan hukum sekunder. Kemudian dengan penalaran deduktif, maka semua bahan hukum yang sudah diseleksi dan diolah disajikan secara apa adanya (deskriptif), sebagai jawaban atas permasalahan yang diteliti.

\section{Hasil dan Pembahasan}

Kedudukan dan keberlakuan yuridis Peraturan Desa menjadi persoalan ketika konfigurasi Peraturan Perundang-Undangan di Indonesia menghilangkan Peraturan Desa dari hierarkhi Peraturan PerundangUndangan di Indonesia yang tercantum dalam Pasal 7 Undang-Undang Nomor 12 Tahun 2011 tentang Pembentukan Peraturan Perundang-Undangan yang selanjutnya disebut sebagai (UU Pembentukan Peraturan Perundang-Undangan). Namun, Peraturan Desa kembali dimunculkan dalam UndangUndang Nomor 6 Tahun 2014 tentang Desa (yang selanjutnya disebut sebagai UU Desa) sebagai wewenang dari desa untuk menyelenggarakan kepentingan pembangunan desa dalam mewujudkan otonomi desa.

Tulisan ini mengangkat permasalahan mengenai kaburnya kedudukan dan keberlakuan Peraturan Desa yang memiliki 
perbedaan dengan tulisan-tulisan terkait Peraturan Desa yang pernah dituliskan sebelumnya. Sebelumnya, telah terdapat tulisan yang mengangkat masalah urgensi dari fungsi Peraturan Desa dalam penyelenggaraan Pemerintahan Desa ${ }^{13}$, membahas mengenai eksistensi Peraturan Desa sebagai Peraturan PerundangUndangan $^{14}$ di mana pada tulisan ini diuraikan secara umum eksistensi Peraturan Desa berdasarkan sejarahnya hingga munculnya UU Desa, namun tidak menguraikan keberlakuan yuridis UU Desa yang membuatnya berbeda dengan tulisan ini. Terdapat juga tulisan yang membahas mengenai rekonstruksi hierarki Peraturan Perundang-Undangan di Indonesia yang membahas Peraturan Perundang-Undangan secara luas dan hanya sedikit menyinggung mengenai Peraturan Desa. ${ }^{15}$ Perbedaan yang dikemukakan di atas memperjelas bahwa tulisan ini merupakan tulisan berbeda yang dapat memberikan dimensi pemahaman yang lebih luas mengenai Peraturan Desa di Indonesia.

13 Ari Wuisang, 2018, Reposisi Peraturan Desa Dalam Hierarki Perundang-Undangan, Jurnal Pakuan Law Review, Volume IV, Nomor 1, Januari-Juni, hlm. 91-110.

${ }^{14}$ Janoko, 2017, Eksistensi Peraturan Desa Sebagai Peraturan Perundang-Undangan, Jurnal Discovery, Vol. 2, No. 1, hlm. 50-60.

${ }^{15}$ Zaka Firma Aditya dan M. Reza Winata, 2018, Rekonstruksi Hierarki Peraturan PerundangUndangan di Indonesia, Jurnal Negara Hukum, Vol. 9, No. 1, hlm. 79-100.

\section{Teori Keberlakuan Hukum}

Menurut B. Arief Shidarta, ada ada 3 (tiga) bentuk keberlakuan hukum, bentuk keberlakuan yang pertama adalah keberlakuan sosial atau keberlakuan faktual, yaitu berkenaan dari efektivitas dari kaidah hukum; bentuk keberlakuan yang kedua adalah keberlakuan yuridik, bahwa suatu kaidah hukum dibentuk sesuai aturan-aturan hukum yang berlaku oleh badan yang berwenang, dan secara substansial tidak bertentangan dengan kaidah-kadiah hukum lainnya (terutama yang lebih tinggi); bentuk keberlakuan terakhir adalah keberlakuan normatif, yang dipersoalkan adalah kualitas (atau legitimasi) dari hukum. Jika salah satu (atau lebih) dari tiga momen itu tidak ada, maka hilanglah keberlakuan dari hukum itu. $^{16}$

Demikian pula Soerjono Soekanto dan Mustafa Abdullah, menyebutkan bahwa ada tiga macam hal berlakunya hukum sebagai kaedah, yaitu:

1) Kaedah hukum berlaku secara yuridis, apabila penentuannya didasarkan pada kaidah yang lebih tinggi tingkatnya, atau bila berbentuk menurut cara yang telah ditetapkan, atau apabila menunjukkan hubungan keharusan antara suatu kondisi dan akibatnya;

2) Kaedah hukum berlaku secara sosiologis, apabila kaedah tersebut

\footnotetext{
${ }^{16}$ B.Arief Shidarta, Meuwissen Tentang Pengembangan Hukum, Ilmu Hukum, Teori Hukum dan Filsafat Hukum, Refika Aditama, Bandung, 2008, h. $46-48$
} 
efektif. Artinya, kaedah tersebut dapat dipaksakan berlakunya oleh penguasa walaupun tidak diterima oleh warga masyarakat (teori kekuasaan), atau kaedah tadi berlaku karena diterima dan diakui oleh masyarakat (teori pengakuan);

3) Kaedah hukum tersebut berlaku secara filosofis, artinya sesuai dengan cita-cita hukum sebagai nilai positif yang tertinggi. ${ }^{17}$

Bila suatu kaedah hukum hanya berlaku secara yuridis, maka kemungkinan besar kaedah tersebut merupakan kaedah mati (dode regel), kalau hanya berlaku secara sosiologis (dalam arti teori kekuasaan), maka kaedah tersebut menjadi aturan pemaksa (dwangmaatregel), dan apabila hanya berlaku secara filosofis, maka mungkin kaedah hukum tersebut hanya merupakan hukum yang dicita-citakan (ius constituendum)."18

Dari ketiga syarat keberlakuan hukum sebagaimana dikemukakan di atas, maka dalam peneliti ini akan melihat keberlakuan hukum secara normatif atau secara yuridis, yang mempunyai keterkaitan dengan hierarkhi peraturan perundang-undangan.

Menurut Hans Kelsen, bahwa "Norma yang menentukan pembuatan norma lain adalah superior, sedangkan norma yang dibuat adalah inferior. Tata hukum, khususnya sebagai personifikasi negara merupakan suatu sistem hierarkhis dari norma-norma yang memiliki level yang berbeda. Kesatuan norma ini disusun oleh fakta bahwa pembuatan norma yang lebih rendah ditentukan oleh norma lain yang lebih tinggi. Pembuatan yang ditentukan oleh norma yang lebih tinggi menjadi alasan utama validitas keseluruhan tata hukum yang membentuk kesatuan."19

\section{Menurut B.Hestu Cipto Handoyo,} bahwa persyaratan yuridis dari peraturan perundang-undangan, salah satunya "Tidak boleh bertentangan dengan peraturan perundang-undangan yang lebih tinggi tingkatannya. Sesuai dengan pandangan stuffenbouwtheory, Peraturan Perundang-undangan mengandung normanorma hukum yang sifatnya hierarkhis. Artinya suatu Peraturan Perundangundangan yang lebih tinggi tingkatannya merupakan grundnorm (norma dasar) bagi Peraturan Perundang-undangan yang lebih rendah tingkatannya. Oleh sebab itu Peraturan Perundang-undangan yang lebih rendah tingkatannya tidak boleh melanggar kaidah hukum yang terdapat di dalam Peraturan Perundang-undangan yang lebih tinggi tingkatannya.",20

\footnotetext{
${ }^{19}$ Jimly Asshiddiqie, Teori Hans Kelsen Tentang Hukum, Konstitusi Press, Jakarta, 2012, h. 100

${ }^{20}$ B. Hestu Cipto Handoyo, op. cit, h. 71

${ }^{17}$ Soerjono Soekanto dan Mustafa Abdullah, Sosiologi Hukum dalam Masyarakat, Rajawali Pers, Jakarta, 1980, h.13

${ }^{18}$ Ibid, h. 14
} 
Selanjutnya menurut JJ.H.Bruggink, bahwa "Orang berbicara tentang keberlakuan normatif suatu kaidah hukum, jika kaidah itu merupakan bagian dari suatu sistem kaidah hukum tertentu yang di dalamnya kaidah-kaidah hukum itu saling menunjuk yang satu terhadap yang lain. Sistem kaidah hukum yang demikian itu terdiri atas suatu keseluruhan hierarkhi kaidah hukum khusus yang bertumpu pada kaidah-kaidah hukum umum. Di dalamnya kaidah hukum yang lebih rendah diderivasi dari kaidah hukum yang lebih tinggi." 21

Dari pendapat-pendapat di atas, maka diambil pemahaman bahwa keberlakuan hukum secara normatif, atau yuridis, dalam hal ini keberlakuan Peraturan Pemerintah apabila memiliki kecocokan dalam sistem hukum hierarkhis, di mana Peraturan Pemerintah tidak boleh bertentangan dengan peraturan yang lebih tinggi.

Penyusunan norma Peraturan Daerah tentang Badan Permusyawaratan Desa harus taat asas terhadap asas dan prinsip umum pembentukan peraturan perundang-undangan, baik aspek formal dalam pembentukannya maupun aspek substansial yang berkenaan dengan materi muatan peraturan perundang-undangan,

${ }^{21}$ JJ..Buruggink, Refleksi Tentang Hukum, alih bahasa Arief Sidharta, Citra Aditya Bakti, Bandung, 1996, h. 150-151. sebagaimana diatur dalam UndangUndang Nomor 12 Tahun 2011 tentang Pedoman Pembentukan Peraturan Perundang-undangan.

Berdasarkan Pasal 5 UndangUndang Nomor 12 Tahun 2011 tentang Pedoman Pembentukan Peraturan Perundang-undangan, ditentukan bahwa:

Dalam membentuk Peraturan Perundang-undangan harus dilakukan berdasarkan pada asas Pembentukan Peraturan Perundangundangan yang baik, yang meliputi: a. kejelasan tujuan; b. kelembagaan atau pejabat pembentuk yang tepat; c. kesesuaian antara jenis, hierarki, dan materi muatan; d. dapat dilaksanakan; e. kedayagunaan dan kehasilgunaan; f. kejelasan rumusan; dan g. keterbukaan.

\subsection{Asas Kelembagaan atau Pejabat}

\section{Pembentuk yang Tepat}

Raperda tentang Badan Permusyawaratan Desa dibentuk atas usul pemerintah daerah dalam hal ini Bupati Bengkulu Tengah, melalui Bagian Administrasi Pemerintahan Kabupaten Bengkulu Tengah, sebagai lembaga yang diberi wewenang menangani urusan pemerintahan desa.

Bupati sebagai pengusul Raperda menyampaikan Raperda ini kepada DPRD Kabupaten Bengkulu Tengah untuk mendapat pembahasan dan persetujuan bersama. Dengan demikian, dari aspek asas kelembagaan, kewenangan Bupati 
Bengkulu Tengah mengajukan usul pembentukan Raperda ini sudah sesuai dengan peraturan perundangundangan.

\section{Badan Permusyawaratan Desa}

Otonomi Desa sebenarnya dapat dipandang sebagai wahana untuk memperkuat sistem demokrasi dalam arti bahwa kedaulatan rakyat memperoleh peluang untuk berproses ke arah perwujudannya secara nyata. Hal ini bisa dimaklumi, karena esensi ekonomi adalah desentralisasi yang tidak hanya berada dalam konteks hubungan antara pemerintah pusat, daerah dan desa, yaitu terutama yang berkaitan dengan penyerahan wewenang pemerintahan oleh pemerintah pusat kepada daerah, khususnya desa. Peranan Badan Permusyawaratan Desa harus dilibatkan secara nyata dalam segala penetapan kebijakan pemerintahan desa. Badan Permusyawaratan Desa harus benar-benar dapat menjadi forum perwakilan rakyat desa. Itulah yang menjadi dasar pemikiran yang menentukan perumusan pasal-pasal tentang hak dan kewajiban serta wewenang Badan Permusyawaratan Desa, sehingga memberikan kewenangan yang begitu besar kepada Badan Permusyawaratan Desa, yang melakukan pengawasan atau kendali terhadap kemungkinan terjadinya ekses atas penggunaan kekuasaan kepala desa.
Pengaturan kewenangan Badan Permusyawaratan Desa tersebut disertai dengan pembatasan kewenangan, sehingga dalam menjalankan tugas dan fungsinya, Badan Permusyawaratan Desa tidak bertindak sewenang-wenang.

$$
\text { Apabila dicermati ternyata }
$$

kewenangan dari Badan Permusyawaratan Desa menurut Undang-Undang Desa, di mana secara implisit dimaknakan bahwa hubungan antara pemerintah desa dengan Badan Permusyawaratan Desa adalah sejajar dan sebagai mitra.

Penyelenggaraan pemerintahan desa merupakan sub sistem dari sistem penyelenggaraan pemerintahan nasional, di mana desa mempunyai hak kewenangan untuk mengatur dan mengurus kepentingan masyarakatnya. Dengan konsekuensi kepala desa bertanggungjawab kepada Bupati dan memberikan keterangan laporan pelaksanaan tugas tersebut kepada rakyat melalui Badan Permusyawaratan Desa.

Pertanggungjawaban Kepala Desa disampaikan kepada Badan Permusyawaratan Desa sekali dalam setahun pada setiap tahun anggaran dan apabila pertanggungjawaban Kepala Desa ditolak oleh Badan Permusyawaratan Desa, maka untuk kedua kalinya pertanggungjawaban tersebut dilengkapi dan disempurnakan, namun apabila untuk kedua kalinya tetap ditolak, maka Badan 
Permusyawaratan Desa mengusulkan pemberhentian Kepala Desa kepada Bupati selaku kepala daerah untuk diproses labih lanjut. Mekanisme seperti ini dilakukan agar sendi tanggungjawab pelaksanaan pemerintahan yang dilakukan Kepala Desa kepada rakyat melalui Badan Permusyawaratan Desa dapat dilihat sebagai perwujudan dari kedaulatan rakyat, atau dalam perkataan lain adalah wujud demokrasi ditingkat desa. Sebab pilar-pilar demokrasi akan terbangun dari bawah. Dengan demokrasi yang dikembangkan dari bawah, maka akan tercipta mekanisme pola hubungan yang seimbang antara pemerintah desa dengan rakyat desa, yang difasilitasi dalam wadah badan/lembaga perwakilan desa.

Selain itu mengenai sumber penerimaan daerah dan pengelolaan keuangan daerah harus berdasarkan ketentuan-ketentuan yang berlaku, di mana Kepala Desa bersama Badan Permusyawaratan Desa menetapkan Anggaran Pendapatan dan Belanja Desa setiap tahun dengan peraturan desa. Pedoman penyusunan anggaran pendapatan dan belanja desa ditetapkan oleh Bupati sebagai kepala daerah kabupaten yang bersangkutan dan diserahkan kepada desa yang memuat aturan-aturan tentang tata cara penyusunan anggaran; tata usaha keuangan desa; mekanisme dan persyaratan pengangkatan bendaharawan desa; pelaksanaan anggaran; perubahan anggaran; perhitungan anggaran; mekanisme pelaporan dan bentuk-bentuk pertanggungjawaban keuangan desa; dan mekanisme pengawasan pelaksanaan anggaran oleh BPD.

Peraturan Daerah Kabupaten yang mengatur mengenai desa, khususnya yang menyangkut tentang Pendapatan Asli Desa sebelum ditetapkan oleh kepala desa beserta Badan Permusyawaratan Desa harus disosialisasikan terlebih dahulu kepada pihak-pihak terkait, seperti lembaga adat, khususnya masyarakat desa, sehingga pemerintahan desa diharapkan dapat menjadi pilar-pilar demokrasi di desa yang dapat menciptakan pemerintahan yang bersih serta bebas dari Korupsi, Kolusi dan Nepotisme.

Pembangunan desa dapat berjalan kalau sejumlah persyaratan dapat dipenuhi, khususnya pertanggungjawaban dari lembaga perwakilan desa, yakni Badan Permusyawaratan Desa kepada masyarakat desa. Pertanggungjawaban Badan Permusyawaratan Desa tetap ada/melekat, baik secara pribadi maupun atas nama lembaga tersebut kepada rakyat desa. Sebab, lembaga tersebut dibentuk dan diwakili masyarakat desa yang keanggotaannya direkrut melalui pemilihan oleh penduduk/masyarakat desa 
setempat dari calon-calon yang memenuhi persyaratan.

Adapun fungsi utama Badan Permusyawaratan Desa adalah menampung, menyalurkan serta mewujudkan aspirasi dan kepentingan masyarakat desa dalam menetapkan kebijakan yang akan dilaksanakan oleh pemerintah desa. Selain Badan Permusyawaratan Desa tersebut terdapat Lembaga Kemasyarakatan Desa seperti; LKMD, Karang taruna, PKK dan kelompok-kelompok masyarakat lainnya sebagai mitra pemerintah desa dalam upaya mewujudkan pemberdayaan masyarakat dan untuk mengakomodasikan aspirasi kebutuhan dan tuntutan masyarakat dalam bidang pembangunan, pelayanan pemerintahan serta menumbuhkembangkan partisipasi dan semangat gotong-royong.

Dalam pemerintahan desa, mekanisme cheks and balance belum tentu berlaku, karena pada umumnya masyarakat desa masih menganut paham primodial yang bersifat kedaerahan, sehingga konflik dalam penyelenggaraan pemerintahan desa tidak terjadi. Dibentuknya Badan Permusyawaratan Desa yang menyelenggarakan Pemerintah Desa, diharapkan dapat menjadi motor penggerak dinamisme masyarakat desa untuk mencapai keseimbangan dan pemberdayaan lembaga-lembaga dan nilai-nilai lokal yang bersifat kondusif terhadap upaya memelihara harmoni sosial sebagai bagian dari suatu bangsa dan untuk menjamin suksesnya pelaksanaan otonomi desa yang asli dan nyata.

Adanya hubungan yang sangat erat antara efektivitas pemerintahan dengan pelaksanaan demokrasi di bawah dan dari bawah, harus ditempuh dengan memberikan atau menyerahkan pengurusan urusan rumah tangga daerah kepada rakyat daerah itu sendiri dengan jalan melakukan otonomi daerah.

Masyarakat desa adalah subyek pembangunan. Sebagai proses gerakan, Pemerintah Desa dan Badan Permusyawaratan Desa berusaha untuk melaksanakan pembangunan tersebut secara menyeluruh. Sebagai gerakan, maka diperlukan kemampuan untuk menggerakkan masyarakat dalam melaksanakan pembangunan dilandasi kesadaran untuk meningkatkan desa menjadi keadaan yang lebih baik. Dalam hubungan ini, maka peranan kepemimpinan sangat menonjol. meskipun masyarakat pada dasarnya tidak bisa dilepaskan, tetapi keberhasilan pembangunan desa juga tampak besar sekali disebabkan oleh kepemimpinan yang tepat sesuai dengan kondisi masyarakat yang bersangkutan. 
Realisasi pembangunan desa di Kabupaten Bengkulu Tengah tentunya tidak sekedar tugas dan kewajiban dari pemerintah desa (Kepala Desa dan Perangkat Desa), tetapi juga menjadi bagian dari tugas Badan Permusyawaratan Desa. Kerjasama dari kedua lembaga desa ini menjadi salah satu faktor penentu dari keberhasilan pembangunan yang akan dilaksanakan.

Pengamatan menunukkan, dalam implementasinya di desa-desa dalam Kabupaten Bengkulu Tengah, Pemerintah Desa bersama-sama Badan Permusyawaratan Desa, telah mengagendakan beberapa program diantaranya adalah program pembuatan Peraturan Desa (Perdes) siklus tahunan, dimana pada tiap tahun peraturanperaturan desa akan dibuat dan diselesaikan berdasarkan perkembangan dan perubahan serta kebutuhan masyarakat desa bersama-sama antara Badan Permusyawaratan Desa dan Pemerintah Desa.

Keselarasan dalam bidang kerjasama antara Pemerintah Desa dengan Badan Permusyawaratan Desa khususnya dalam pembangunan di bidang pembuatan Perdes harus selalu dapat berkoordinasi dengan pemerintah daerah yang ada sehingga nantinya dapat terwujud sistem pemerintahan yang baik. Setiap peraturan desa yang dirumuskan, seandainya tidak berkenaan dan sesuai dengan peraturan yang lebih tinggi dapat menjadi masukan bagi Pemerintah Daerah Kabupaten Bengkulu Tengah, untuk dipertimbangkan berdasarkan kebutuhan dan kondisi yang terjadi di intern pemerintahan desa dan Badan Permusyawaratan Desa.

Pelaksanaan kerjasama antara Pemerintah Desa dengan Badan Permusyawaratan Desa dimaksudkan agar pembangunan yang akan dilaksanakan oleh pemerintah desa dapat segera terlaksana dan berhasil untuk meminimalisasi terjadinya konflik antara kedua lembaga tersebut dalam bentuk munculnya ketegangan antara kedua lembaga ini perlu kiranya dibuat suatu kesepakatan-kesepakatan baik secara tertulis maupun lisan atau bentuk lainnya yang mengarah kepada terciptanya suasana yang saling mengerti terhadap peran dan fungsi dari masing-masing lembaga. Pilihan regulasi berupa Perda, pada akhirnya membebankan kewajiban kepada Badan Permusyawaratan Desa untuk membentuk peraturan tata tertib dan kode etik Badan Permusyawaratan Desa, yang menjadi pedoman dalam pelaksanaan tugas dan fungsinya. 


\section{Kesimpulan}

Penghapusan peraturan desa dari hierarkhi peraturan perundang-undangan Indonesia dalam Pasal 7 UU Pembentukan Pemerintahan Daerah tidak menimbulkan implikasi terhadap penyelenggaraan pemerintahan desa, karena peraturan desa tetap merupakan peraturan yang mengikat dan juga dikuatkan oleh lahirnya UndangUndang Nomor 6 tahun 2014 tentang Desa. Kedudukan dan keberlakuan peraturan desa dianggap sama kuat dengan aturan-aturan lain yang ada dalam hierarkhi dengan mengau pada prinsip hierarkhi fungsional yang secara eksplisit dapat ditemui normanya dalam Pasal 8 (1) UU Pembentukan Peraturan Perundang-Undangan. Pengaturan peraturan desa secara khusus dalam UU Desa dan mekanisme pembentukannya yang juga secara khusus diatur dalam peraturan pelaksanaannya telah memberikan lex specialis bagi peraturan desa sehingga kehadirannya kini menjadi sebuah keharusan dalam sebuah pemerintahan desa.

\section{Daftar Pustaka}

\section{Buku}

Abdurrahman. (1995). Ilmu Hukum, Teori Hukum dan Ilmu Perundangundangan. Bandung: Citra Aditya Bhakti.

Hanif Nurcholis. (2012). Pertumbuhan dan Penyelenggaraan Pemerintahan Desa. Surabaya: Erlangga.

Hans Kelsen. (1961). General Theory of Law and State. New York: Russel \& Russel.

Moh. Mahfud MD. (2014). Politik Hukum di Indonesia. Jakarta: RajaGrafindo.

Ni'matul Huda. (2015). Hukum Pemerintahan Desa Dalam Konstitusi Indonesia Sejak Kemerdekaan Hingga era Reformasi. Malang: Setara Press.

Ni'matul Huda. (2014). Perkembangan Hukum Tata Negara (Perdebatan dan Gagasan Penyempurnaan).Yogyakarta: FH-UII Press.

Peter Mahmud Marzuki. (2010). Penelitian Hukum. Cetakan ke-6. Jakarta: Kencana Prenada Media Group.

Taufiqurrohman Syahuri. (2011). Tafsir Konstitusi Berbagai Aspek Hukum. Jakarta: Kencana Prenada Media Group.

Zainuddin Ali. (2009). Metode Penelitian Hukum. Jakarta: Sinar Grafika.

\section{Artikel Jurnal}

Ari Wuisang. (2018). Reposisi Peraturan Desa Dalam Hierarki PerundangUndangan. Jurnal Pakuan Law Review. Volume IV. Nomor 1. Januari-Juni.

Janoko. (2017). Eksistensi Peraturan Desa Sebagai Peraturan PerundangUndangan. Jurnal Discovery. Vol. 2. No. 1. 
Zaka Firma Aditya dan M. Reza Winata. (2018). Rekonstruksi Hierarki Peraturan Perundang-Undangan di Indonesia. Jurnal Negara Hukum. Vol. 9. No. 1. 